\title{
First report of Neofusicoccum parvum causing stem blight and dieback of Osmanthus fragrans in China
}

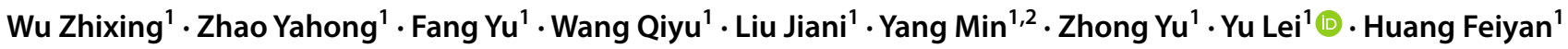

Received: 20 February 2021 / Accepted: 26 August 2021 / Published online: 22 November 2021

(c) The Author(s) 2021

Keywords Stem blight · Osmanthus fragrans $\cdot$ Neofusicoccum parvum

Osmanthus fragrans (Thunb.) Lour is cultivated as an ornamental plant and has high economic value with market potential in China. In September of 2020, symptoms of stem blight were observed on $O$. fragrans in Kunming City. Symptoms included stem and twig dieback, and extensive vascular discoloration. A total of 217 plants were investigated, among which the disease incidence was $13.6 \%$. Samples from plants with symptoms were surface sterilized with $2 \%$ sodium hypochlorite and then $75 \%$ ethanol, plated on potato dextrose agar (PDA), and incubated at $28{ }^{\circ} \mathrm{C}$. Fungal colonies developed copious white aerial mycelium that became dark grey after five days, and formed black pycnidia after 23 days. Conidia forming on PDA were one-celled, fusiform to ellipsoidal, externally smooth and thin walled, with dimensions of 13.5-17.8 ×4.1-6.3 (average $14.2 \times 5.3 \mu \mathrm{m}$ ). Sequencing of ITS1-5.8S-ITS2, $\beta$-tubulin, and EF1- $\alpha$ were performed. BLAST searches at GenBank showed the highest nucleotide sequence identity with Neofusicoccum parvum reference sequence (ITS: 100\%, MH988433; $\beta$-tubulin: $100 \%$, MK563987; EF1- $\alpha$ : 98.08\%, KP183186). Representative sequences of isolates from these regions were deposited in GenBank (ITS: MW617270; $\beta$-tubulin: MW625871; EF1- $\alpha$ : MW625870). Based on the multigene phylogeny and morphology, isolates were identified as N. parvum. Pathogenicity tests were conducted by stem inoculation of 2-year-old $O$. fragrans seedlings. Inoculated and control seedlings were

\footnotetext{
Yu Lei

376914788@qq.com

$\triangle$ Huang Feiyan

125593879@qq.com

1 College of Agronomy/Yunnan Urban Agricultural Engineering \& Technological Research Center, Kunming University, Yunnan Kunming 650214, China
}

2 College of Plant Protection, Yunnan Agricultural University, Yunnan Kunming 650201, China kept in the greenhouse. After 30 days, all the inoculated plants showed tissue discoloration and leaf wilting, but none of the control. $N$. parvum was reisolated from symptomatic tissues, thus fulfilling Koch's postulates. $N$. parvum has been reported as a pathogen causing stem dieback and branch canker on Platanus $\times$ acerifolia (Yu et al. 2018), peach (Zhang et al. 2019) and Hemp (Feng et al. 2020). To our knowledge, this is the first report of N. parvum on O. fragrans in China as well as worldwide.

Supplementary information The online version contains supplementary material available at https://doi.org/10.1007/s42161-021-00936-9.

Funding This research was supported by Yunnan Provincial Department of Science and Technology (No. 2019FH001-051, 2017FH001005, 2017FH001-035, 2018HB100, 2019FH001-008), Teacher Project of Yunnan Education Department (2019J0574).

\section{Declarations}

Ethical approval This article does not contain any studies with human participants or animals performed by any of the authors.

Conflict of interest The authors declare that they have no conflict of interest.

Open Access This article is licensed under a Creative Commons Attribution 4.0 International License, which permits use, sharing, adaptation, distribution and reproduction in any medium or format, as long as you give appropriate credit to the original author(s) and the source, provide a link to the Creative Commons licence, and indicate if changes were made. The images or other third party material in this article are included in the article's Creative Commons licence, unless indicated otherwise in a credit line to the material. If material is not included in the article's Creative Commons licence and your intended use is not permitted by statutory regulation or exceeds the permitted use, you will need to obtain permission directly from the copyright holder. To view a copy of this licence, visit http://creativecommons.org/licenses/by/4.0/. 


\section{References}

Feng C, Villarroel-Zeballos MI, Ficheux PF, Zima H, Dhillon BDS, Correll JC (2020) First report of Neofusicoccum parvum causing dieback and canker disease on hemp in the United States. Plant Dis 104:3075 Plant Dis 101:805

Yu L, Liu JN, Chen ZB, Xu SG, Ren Z, Wang DK, Geng KY, Zhang Q, Pei WH, Kong CS (2018) First report of stem dieback on Platanus $\times$ acerifolia caused by Neofusicoccum parvum in China. Plant Dis 102:1446
Zhang LQ, Li X, Su M, Zhou J, Ye Z (2019) First report of Neofusicoccum parvum associated with shoot cankers of peach (Prunus persica) in Shanghai. China Journal of Plant Pathology 101:1257

Publisher's Note Springer Nature remains neutral with regard to jurisdictional claims in published maps and institutional affiliations. 